\title{
ROADMAPPING IN POLISH FORESIGHT INITIATIVES - BEST PRACTICES
}

\author{
Anna Kononiuk ${ }^{1}$, Alicja E. Gudanowska ${ }^{2}$ \\ Chair of Business Informatics and Logistics, Faculty of Management, \\ Bialystok University of Technology, Wiejska 45A, 15-345 Bialystok, Poland \\ E-mails: ' ${ }^{a} . k o n o n i u k @ p b . e d u . p l ;{ }^{2} a . g u d a n o w s k a @ p b . e d u . p l$ (corresponding author)
}

\begin{abstract}
The aim of the article is to present the best practices of technology roadmapping application to the Polish foresight initiatives. The first part of the article is devoted to presentation of the conceptualisation of the best practices for the context of foresight studies and serves as the proposal of the possible criteria of technology roadmapping method benchmarking. In the second part of the article, there have been presented the results of technology roadmapping evaluation in the context of Polish foresight initiatives with the special emphasis on the best practices. The final part of the article offers recommendations for technology roadmapping application to foresight studies.
\end{abstract}

Keywords: technology roadmapping, foresight, best practices, evaluation, Polish foresight initiatives.

JEL Classification: O21; O32; O33.

\section{Introduction}

Technology roadmapping is a complex approach to strategic planning whose idea manifests itself in integration of science with business practice as well as in identification of chances in the scope of new technologies development (Daim, Oliver 2008; Probert, Radnor 2003). As noted by Kameoka et al. (2003), roadmaps can be presented in various forms, types or with different taxonomies. They can be categorized into science or technology roadmaps, industry roadmaps, product-technology roadmaps, and product roadmaps (Kappel 2001).

Roadmapping as well as technology roadmapping is widely used by researchers as a term denoting various phenomena (Garcia, Bray 1998). The first paper on technology roadmap was published by Motorola, which used this method within production planning. This was aimed at aligning the product strategy with technological plans (Willyard, McClees 1987). Since then the method has been implemented and adapted for the needs of many different organisations in various sectors, companies and at various levels, which assisted in the execution of numerous strategic objectives (Phaal et al. 2005; Moghaddam, Sahafzadeh 2010). This method undergoes constant improvements, becomes implemented in all the latest areas of use or new interrelated concepts that allow for merging with other methods of strategic analysis (Kononiuk, Gudanowska 2013; Phaal et al. 2011).

The method of technology roadmapping is primarily characterised by its correlation to the timeline.
This element recurs in most visualisations. The manner in which the method is carried out is diversified both due to the field of the study, the objective of conducted analysis as well as the group of its recipients. High diversification also characterises the forms used for presenting the results of the method upon its execution. With regard to the objective of constructing the developmental route, one can enumerate visualisations created within: strategic planning, long-term planning, product, capability, knowledge capital, programme, process and integration. The time perspective presented in the final paper primarily hinges upon the channelling of the developmental route. The ones devised for the needs of the enterprises take the perspective of 5 years (in the case of product development) or 10-15 years (in the case of technology development considered by scientific institutes or public administration bodies). However, those created for scientific and research needs reach $20-30$ years. A key issue in developing the construction of a developmental route which complements the content analysis of its individual layers rests in their mutual relations. Aligning various perspectives in one formula should allow for the mechanism of market pull and technology push. They may be created on the basis of expertise, through engaging diversified representatives of interested parties, and/or result from computer-processed quantitative data. A properly developed technology roadmap supports 
the planning process, enables identification and comprehension of the company's objectives and the means of their execution; it assists in determining the adequate developmental direction of technologies of key significance and concentrating on resources indispensable for this cause, and thereby creating recommendations concerning the investment and allocation of financial means (Skulimowski 2009; Phaal et al. 2000; Phaal et al. 2001; Muller 2008; Albright 2009; Wierzbicki, Nakamori 2007).

Among other methods, technology roadmapping is frequently applied in foresight studies. In Poland over 40 foresight-oriented initiatives have been conducted in 11 voivodships (Nazarko 2012). The resulting analyses point to the identification of 8 projects which involved the method described as roadmapping or technology roadmapping, or at times there even appeared elements that were coherent with them. The process of their selection is one of the elements of scientific procedure described in the further part of the publication.

On the basis of the overview of available databases on roadmapping activities such as: roadmapping exercises in the public sector available on the website of the University of Cambridge, European Foresight Monitoring Network, European Foresight Platform, one may identify many possible approaches to roadmaps construction. The critical analysis of the existing published works of authors such as Daim et al. (2012), Caetano, Amaral (2011), Ahlqvist et al. (2012), Saritas, Aylen (2010), Eerola, Miles (2011), Lee et al. (2012) also confirms the authors' observations in that respect. However, in the existing published works, the authors of this article have not come across a publication which at the same time offers best practices of the method application as well as useful guidelines for its possible practitioners. Therefore, the main focus of this publication is to fill this knowledge gap in the context of Polish foresight initiatives.

\section{Best practices - the notion and selection criteria}

In the literature on the subject, identification of best practices comes down to a technique, a method, a process, an action or a mechanism used in order to optimize the results of production or management practices, as well as to minimize the potential for errors. P. Keehley indicates that, in spite of research being quite common, there is a cognitive dissonance of the notion of a best practice in the literature. She also distinguishes three ways of defining a best practice (Keehley et al. 1997; Xu, Yeh 2011):
- a best practice is every practice better than the current one - the evaluation of practice quality is strongly connected with both the individual who has identified the best practice and the organisation in which it has been identified; implementation of a best practice interpreted in such a way is assessed as very risky;

- a best practice is the one thought to be a best practice by others, especially by the media which present the given practice in a context of success of the organisation that applies it; such assessment is rather a public opinion's acknowledgement of a practice as the best one, often without its consistent examination and defining;

- a best practice is the one chosen in a competition procedure; the win of a given organisation indicates that the best practice will be executed in the given area of activity.

According to Yan Xu and Chung-Hsing Yeh, the basic features of the best among good practices are their repeatability and versatility. Only the practices which have been thoroughly investigated and applied in numerous organisations and projects do stand a chance for a label of a best practice. One can focus here on a process-oriented approach (an action or a sequence of actions which optimize an existing process) and an approach oriented to the results of a given practice (action or approach providing value to its executors or allowing for gaining advantage over others) (Xu, Yeh 2011).

Important issues concerning applied practices are: firstly, identification of criteria which condition best practices, and then their implementation in a new environment. Literature provides some advice on how to choose best practices. Criteria and attributes of best practices can be isolated among them. The assumed criteria, among others, are the following (Xu, Yeh 2011; Keehley et al. 1997):

- measurability of results - the success of a practice is conveyed through its outcome, effect, timeliness, effectiveness;

- extent of impact on achieving goals assumed in the undertaking (in the case of difficulty with results quantification of practice application);

- repeatability, with taking into account a modification possibility;

- local importance;

- openness of the adopted procedure;

- lack of connection to environment specificity or application conditions, universality of use. 
Attributes of a best practice relate to such its aspect as a need of reference to a common vision and a need of deeming it inventive or innovative in the aspect of some practice modifications, so as not to constitute just an incremental change in the context of a natural development of the approach (Tindigarukayo 2012; Karwińska, Wiktor 2008). Moreover, a good practice should (Tindigarukayo 2012; Kasprzak 2005):

- be effective even with time,

- bring about better results to followers,

- adopt a character of methodical procedure.

It ought to be noted that the enumerated criteria and attributes are not mutually exclusive, do not constitute a closed set of conditions and features. Their final selection and their delineation in a specific area should be determined by the subject of the practices.

\section{Identification of good practices in the scope of applying the method of technologies development routes in Polish foresight projects}

In the first stage of selecting Polish best practices, projects have been identified in accordance with the adopted border conditions (Rogut et al. 2009). The analysis encompassed initiatives which fulfilled the following assumptions:

- a foresight project;

- a project executed in Poland;

- a project in which there have been identified elements coherent with the idea of technology roadmapping.

Studies have allowed for identification of ten initiatives, in which there have been identified practices in the area of the methodology of creating technology roadmaps. In the following stage, there have been distinguished criteria allowing for selecting the best practice. Those criteria are the following:

(a) universality of the practice - easy access to documentation on the scope of the practice, especially clarity and accessibility of the description of the adopted methodological procedure;

(b) repeatability - a possibility of applying a given practice or its modification again in another foresight project, regardless of the specificity of the region or sector in which the project was executed;

(c) the practice has assumed a character of methodical procedure;

(d) the practice constitutes a novel solution compared to other popularly used solutions.
The evaluation of identified practices was done based on the following adopted scale:

$\begin{array}{ll}* * * & \begin{array}{l}\text { procedure adopted in the project } \\ \text { satisfies the criteria to a high degree }\end{array} \\ * * & \begin{array}{l}\text { procedure adopted in the project } \\ \text { satisfies the criteria to some extent }\end{array} \\ * & \begin{array}{l}\text { procedure adopted in the project } \\ \text { satisfies the criteria to a low degree }\end{array}\end{array}$

In case of two out of ten projects, namely (i) Economic networks of Wielkopolskie voivodship - scenarios of knowledge transformation supporting innovative economy and (ii) Identification of potential and resources of Lower Silesia in the scope of knowledge and technology for the enhancement of the quality of life and setting the future trajectories of development. Research based on foresight methods, there were used selected elements of roadmapping approach. In both cases, the context of the technology was not taken into account. Therefore, the evaluation was made for eight initiatives.

The evaluation of the practices described in the following chapters, with the use of the assumed criteria, was done by members of a key research team from the Bialystok University of Technology, as an inside expert panel for the NPF-results implementation project.

With reference to technology roadmapping, those experiences in foresight project execution were regarded as best practices which in expert opinion meet the four criteria at the same time, i.e. universality of a given practice, its repeatability, documented methodical procedure and a novel solution.

The marks awarded by the experts are presented in Table 1.

For the best practices of roadmapping activity have been chosen those foresight initiatives, in which at least one criterion has been met to a high degree, which is the case in six out of eight analysed projects. The attributes of technology roadmapping best practices have been presented in Table 2 .

As it was mentioned in the introduction, technology roadmaps may appear in the graphic form. One of the main problems in the course of conducting the method is the number of specific forms of roadmaps which frequently need to be adjusted to specific needs and contexts. The source literature points to a number of visualisations. Apart from area charts these may as well include: band charts, histograms, tables, graphs, pictograms, data flow 
diagrams, single layers or texts (Phaal et al. 2001). While analysing projects with regard to the problems with choosing the right form of the roadmap, as mentioned in the source literature, the paper focuses not only on the analysis of the manner of method execution in a given project, but also in selected forms of graphic presentations devised by roadmap executors.

The attributes which appear in the described projects and which can be named best practices are:

- drawing on the established in the literature on the subject R. Phaal's concept of technology roadmapping;

- developing the roadmap by an interdisciplinary expert team;

- indicating connections between the technology roadmapping and strategic documents;

- expert consultation on potential elements of layers which represent the technologies development route;

- integrating the achievements of other project's panels' work for the sake of the method;

- setting detailed activities for results' implementation;

- offering advice on possible funding sources;

- establishing a list of organizations which are to play the key role in results' implementation;
- identifying the scope and deadline of research implementation activities.

Out of all adduced best practices in technology roadmapping, projects Advanced industrial and ecological technologies for the country's sustainable development deserves special mention and Technological foresight $<<N T$ FOR Podlaskie 2020>> A regional strategy of nanotechnology development.

In the article authors' opinion, the first one fulfilling the adopted criteria of identifying a best practice to a pre-eminent degree makes it justified to perceive the manner of creating technology roadmaps from the angle of referential methodology which can be implemented in subsequent foresight projects. In this project, to prepare the technology roadmaps was involved interdisciplinary team of experts, both external and internal. The result of the analyzes of the technical support of sustainable development was prepared technology roadmaps in the various thematic areas, consisting of two layers. Layer "product" included priority technologies, and a layer of "resources" refer to the skills and competencies necessary to manufacture the products. The executors of the project creating technology roadmaps have taken into account the relationship between the individual layers (Mazurkiewicz, Poteralska 2011). General scheme of technology roadmap in the project is presented in Figure 1.

Table 1. Experts' evaluation in area of technology roadmapping (Source: Nazarko et al. 2012)

\begin{tabular}{|c|c|c|c|c|}
\hline Project & Universality & Repeatability & $\begin{array}{l}\text { Methodical } \\
\text { character }\end{array}$ & Inventiveness \\
\hline $\begin{array}{l}\text { Technological development scenarios of the fuel } \\
\text { and energy complex for the country's energetic } \\
\text { security }\end{array}$ & $* *$ & $* * *$ & $* *$ & $* *$ \\
\hline $\begin{array}{l}\text { Technological foresight }<<\text { NT FOR Podlaskie } \\
2020>>\text { A regional strategy of nanotechnology } \\
\text { development }\end{array}$ & $* *$ & $* * *$ & $* * *$ & $* * *$ \\
\hline $\begin{array}{l}\text { Technology foresight of public services develop- } \\
\text { ment in Metropolitan Area of Upper Silesia }\end{array}$ & $* * *$ & $* * *$ & $* *$ & $* *$ \\
\hline $\begin{array}{l}\text { Advanced industrial and ecological technologies } \\
\text { for the country's sustainable development }\end{array}$ & $* * *$ & $* * *$ & $* * *$ & $* * *$ \\
\hline $\begin{array}{l}\text { Priority technologies for sustained development } \\
\text { of the Podkarpackie Voivodship }\end{array}$ & $* *$ & $* * *$ & $* *$ & $* *$ \\
\hline $\begin{array}{l}\text { The Technology Perspective Kraków-Matopolska } \\
2020\end{array}$ & $* * *$ & $* * *$ & $* *$ & $* *$ \\
\hline $\begin{array}{l}\text { Regional foresight of the Zachodniopomorskie } \\
\text { Voivodship }\end{array}$ & $*$ & $* *$ & $*$ & $*$ \\
\hline Technology foresight for industry INSIGHT 2030 & $* *$ & $* *$ & $*$ & $* *$ \\
\hline
\end{tabular}


Table 2. Attributes of best practices in the scope of roadmapping activity (Source: created by the autors)

\begin{tabular}{|c|c|}
\hline Project & Attributes of best practices \\
\hline $\begin{array}{l}\text { Advanced industrial and } \\
\text { ecological technologies for } \\
\text { the country's sustainable } \\
\text { development }\end{array}$ & $\begin{array}{l}\text { - drawing on the established in the literature on the subject } \mathrm{R} \text {. Phaal's concept of } \\
\text { technology roadmapping } \\
\text { - developing the roadmap by an interdisciplinary expert team } \\
- \text { offering recommendations for decision makers responsible for technological and } \\
\text { innovative policy } \\
\text { - technology roadmaps construction was supported by elements of current state of } \\
\text { technology diagnosis }\end{array}$ \\
\hline $\begin{array}{l}\text { Technological foresight } \\
<<\text { NT FOR Podlaskie } \\
2020>>\text { A regional strate- } \\
\text { gy of nanotechnology de- } \\
\text { velopment }\end{array}$ & $\begin{array}{l}\text { - drawing on the established in the literature on the subject R. Phaal's concept of } \\
\text { technology roadmapping in therm of defying roadmap layers such as resources, } \\
\text { market, technology, R\&D, applications } \\
\text { - } \text { taking into account a technology planning framework } \\
\text { - } \text { expert consultation on potential elements of layers which represent the technolo- } \\
\text { gies development route } \\
\text { - } \text { integrating the achievements of other project's panels' work for the sake of the } \\
\text { method } \\
\text { - } \text { the connection of the roadmapping activity with the project of regional strategy of } \\
\text { nanotechnology development } \\
\text { - technology roadmaps construction was preceded by a stage of technology map- } \\
\text { ping }\end{array}$ \\
\hline $\begin{array}{l}\text { logical development } \\
\text { os of the fuel and } \\
\text { complex for the } \\
\text { 's energetic security }\end{array}$ & $\begin{array}{l}\text { - drawing on the established in the literature on the subject R. Phaal's concept of } \\
\text { technology roadmapping in terms of defining roadmap layers } \\
\text { - identifying the scope and deadline of research implementation activities }\end{array}$ \\
\hline $\begin{array}{l}\text { FORGOM- Technology } \\
\text { foresight of public services } \\
\text { development in Metropoli- } \\
\text { tan Area of Upper Silesia }\end{array}$ & $\begin{array}{l}\text { - drawing on the established in the literature on the subject R. Phaal's concept } \\
\text { - } \text { offering recommendations for the decision makers, public central administration } \\
\text { and local authorities } \\
\text { - } \text { integrating the achievements of other project's panels' work for the sake of the } \\
\text { method } \\
\text { - developing the roadmap by an interdisciplinary expert team } \\
-\quad \text { technology roadmaps construction was supported by elements of current state of } \\
\text { technology diagnosis }\end{array}$ \\
\hline $\begin{array}{l}\text { The Technology Perspec- } \\
\text { tive Kraków-Matopolska } \\
2020\end{array}$ & $\begin{array}{l}\text { - drawing on the established in the literature on the subject R. Phaal's concept } \\
\text { - developing the roadmap by an interdisciplinary expert team } \\
\text { - technology roadmaps construction was supported by elements of current state of } \\
\text { technology diagnosis }\end{array}$ \\
\hline $\begin{array}{l}\text { Priority technologies for } \\
\text { sustained development of } \\
\text { the Podkarpackie Voivod- } \\
\text { ship }\end{array}$ & 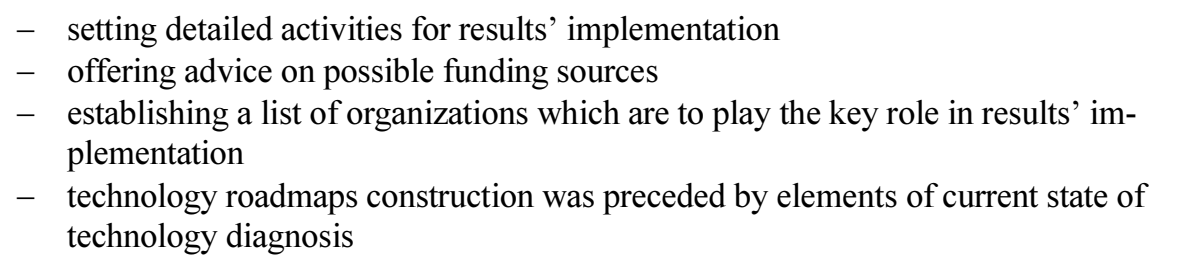 \\
\hline
\end{tabular}

In case of second one, only the universality has not been evaluated in the highest degree. In this project, it was agreed that the process of construction technology roadmaps will be supported by an expert consultation on potential elements of layers representing the technology roadmap. Experts rate layers of roadmap in three time perspectives - 2012-2014, 2018-2020 and 2015-2017. The final version included four layers: (1) resour- ces (by the human, material, financial), (2) R\&D layer (divided into basic research, implementation, development trends), (3) areas of potential applications, and (4) technological development (Kononiuk, Gudanowska 2013). Graphical representation of technology roadmap was inspired visualization of megatrends shaping the reality according to R. Watson (Watson 2012). The base concept prepared for the project is shown in Figure 2. 


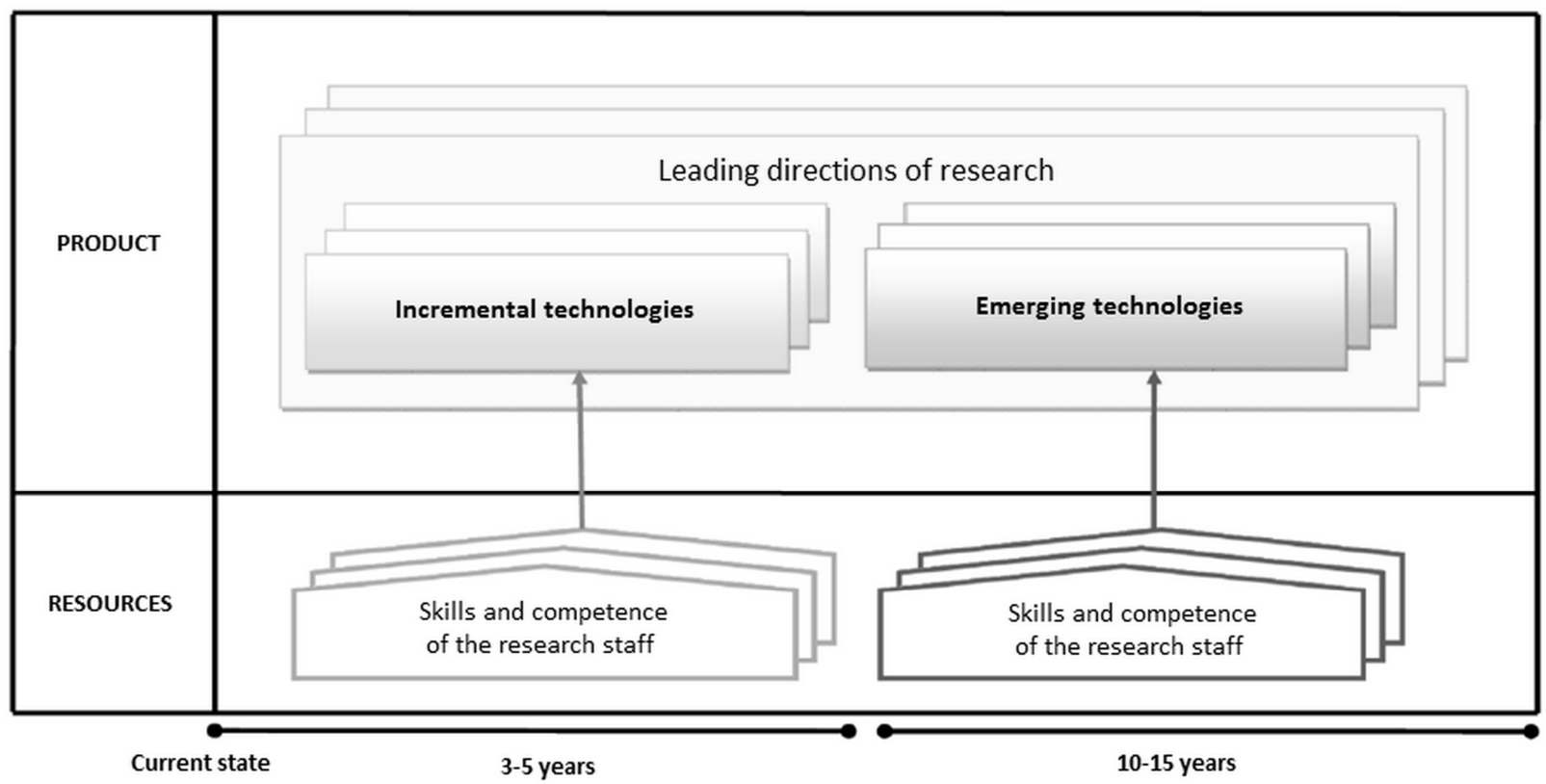

Fig. 1. General scheme of technology roadmap in the project Advanced industrial and ecological technologies for the country's sustainable development deserves special mention

(Source: Mazurkiewicz, Poteralska 2011)

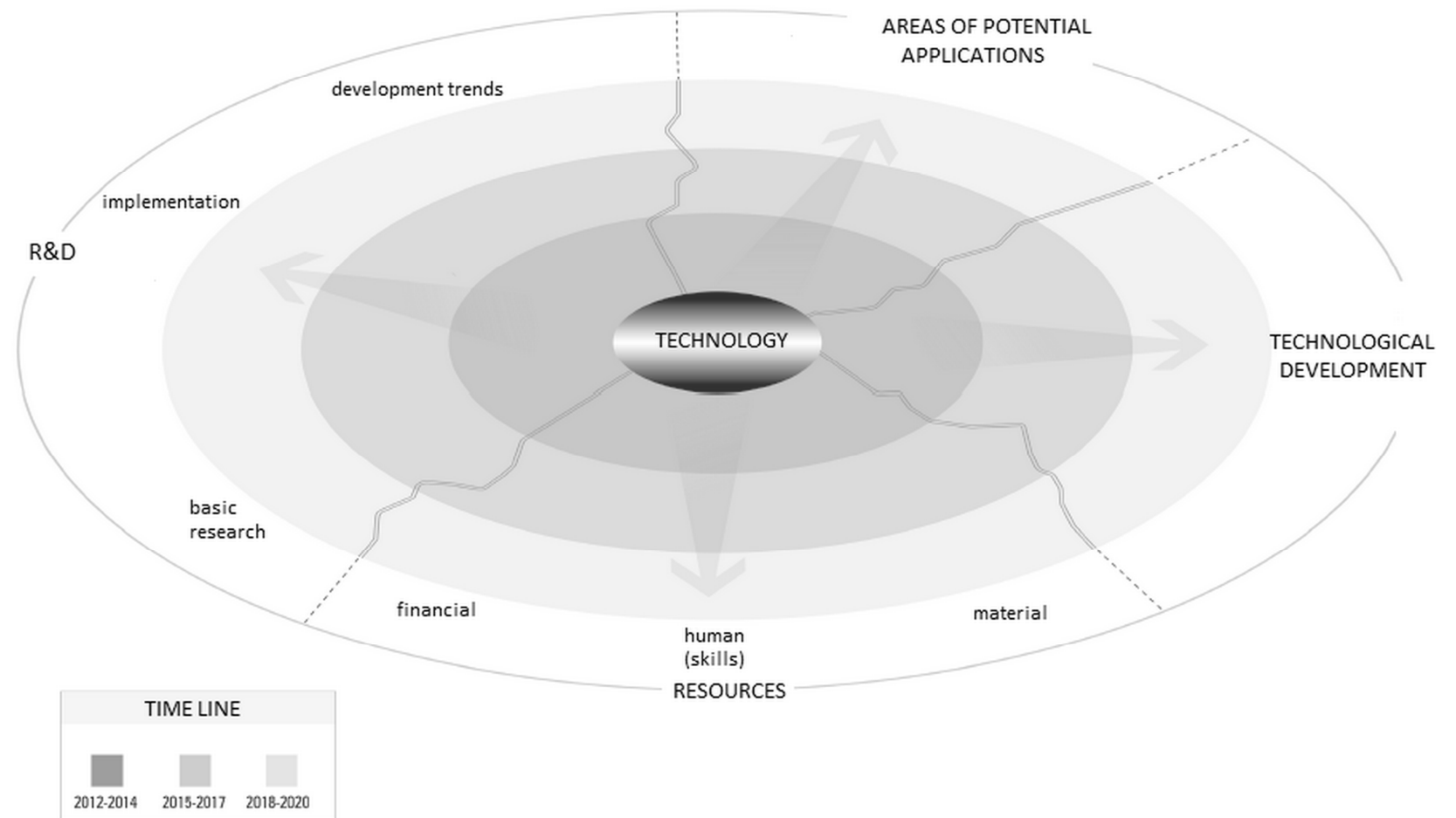

Fig. 2. The base concept of technology roadmap prepared in the project Technological foresight $<<$ NT FOR Podlaskie 2020>> A regional strategy of nanotechnology development

(Source: Kononiuk, Gudanowska 2013) 


\section{Summary and recommendations for roadmapping application to foresight practice}

A critical analysis of publications on the roadmapping method and on best practices issues as well as a synthesis of studies on the method application to Polish foresight practice allowed for drawing up evaluation criteria for best practices, indicating referential projects in which the method was used, as well as formulating recommendations on applying the method in foresight practice.

Due to the complexity of the method, it is essential to choose one concept of creating roadmaps in scope of a project and to apply it consistently when more than one roadmap is created in a project. The authors recommend the grounded in literature R. Phaal's concept based on building multilayered time graphs; it also advises to incorporate a technology planning framework in creating routes, especially when the central layer of the route is a technology layer. It is recommended that technology roadmaps construction should be preceded by a stage of technology mapping, which will allow for indication of a starting point for the development of technologies in time, as well as for identification of connections among technologies which can be transferred directly onto the roadmap. What is more, it is useful to conduct expert consultation on individual roadmap layers and elements which are to be located on it. Moreover, in order to enhance effectiveness of communicating the roadmap content, incorporate multidimensionality of the environment and improve implementation ability, the roadmap should: integrate achievements of all project's thematic panels, be developed by an interdisciplinary expert team and be connected with strategic documents. It also seems legitimate to incorporate the scenario method in the process of technology roadmapping (because of, for instance, a broad context, encompassing many factors and spheres which make up development conditions of a given area). Finally, technology roadmaps should not only indicate development directions, but also aid identification of corrective and preventive actions.

\section{Acknowledgements}

The research were conducted within S/WZ/1/2014 project and were financed from Ministry of Science and Higher Education funds

\section{References}

Ahlqvist, T.; Valovirta, V.; Loikkanen, T. 2012. Science \& Public Policy (SPP), Innovation Policy Roadmapping as a Systemic Instrument for ForwardLooking Policy Design 39(2): 178-190.
Albright, R. E. 2009. Visualization in strategic and technology roadmapping, in Proceedings of the Portland International Conference on Management of Engineering and Technology, 2-6 August 2009, Portland, USA, 2466-2474.

Caetano, M.; Amaral, D. C. 2011. Roadmapping for technology push and partnership: a contribution for open innovation environments, Technovation 31(7): $320-335$.

http://dx.doi.org/10.1016/j.technovation.2011.01.005

Daim, T. U.; Amer, M.; Brenden, R. 2012. Technology Roadmapping for wind energy: case of the Pacific Northwest, Journal of Cleaner Production 20(1): 27-37. http://dx.doi.org/10.1016/j.jclepro.2011.07.025

Daim, T. U.; Oliver, T. 2008. Implementing technology roadmap process in the energy services sector: a case study of a government agency, Technological Forecasting \& Social Change 75(5): 687-720. http://dx.doi.org/10.1016/j.techfore.2007.04.006

Eerola, A.; Miles, I. 2011. Methods and tools contributing to FTA: a knowledge-based perspective, Futures 43(3): 265-278. http://dx.doi.org/10.1016/j.futures.2010.11.005

Garcia, M. L.; Bray, O. H. 1998. Fundamentals of technology Roadmapping, NM: Sandia National Laboratories, Report SAND97-0665, Albuquerque: 3-34.

Kameoka, A.; Kuwahara, T.; Li, M. 2003. Integrated strategy development: an integrated roadmapping approach, in Proceedings of the Portland International Conference on Management of Engineering and Technology, 20-24 July 2003, Portland, USA, 370-379.

Kappel, T. A. 2001. Perspectives on roadmaps: how organisations talk about the future, Journal of Product Innovation Management 18(1): 39-50. http://dx.doi.org/10.1016/S0737-6782(00)00066-7

Karwińska, A.; Wiktor, D. 2008. Przedsiębiorczość $i$ korzyści społeczne: identyfikacja dobrych praktyk $w$ ekonomii spolecznej. Fundacja Inicjatyw Społeczno-Ekonomicznych.

Kasprzak, T. (Ed.). 2005. Modele referencyjne $w$ zarzadzaniu procesami biznesu. Warszawa: Studia Informatyki Gospodarczej, Difin.

Keehley, P.; Medlin, S.; MacBride, S.; Longmire, L. 1997. Benchmarking for best practices in the public sector: achieving performance breakthroughs in federal, state, and local agencies. San Francisco: Jossey-Bass Inc. Publishers.

Kononiuk, A.; Gudanowska, A. (Eds.). 2013. Kierunki rozwoju nanotechnologii $w$ województwie podlaskim. Mapy. Marszruty. Trendy, Politechnika Białostocka, Białystok.

Kononiuk, A.; Nazarko, Ł.; Nazarko, J.; Ejdys, J.; Halicka, K.; Glińska, U.; Gudanowska, A. 2012. Nanotechnology for Podlaskie 2020. European Foresight Platform, Brief 235 [online], [cited 01 December 2015]. Available from Internet: http://www.foresight-platform.eu 
Lee, J. H.; Kim, H.; Phaal, R. 2012. An analysis of factors improving technology roadmap credibility: A communications theory assessment of roadmapping processes, Technological Forecasting \& Social Change 79(2): 263-280. http://dx.doi.org/10.1016/j.techfore.2011.05.003

Mazurkiewicz, A.; Poteralska, B. 2011. Zaawansowane technologie przemystowe i ekologiczne dla zrównoważonego rozwoju kraju, Wydawnictwo Naukowe Instytutu Technologii Eksploatacji - Państwowego Instytutu Badawczego, Radom.

Moghaddam, N. B.; Sahafzadeh, M. 2010. Technology research roadmapping: the case study of membrane technology in Iranian Petrochemical Industry, Management Science and Engineering 4(3): 128 137.

Muller, G. 2008. Roadmapping. Philips Embedded Systems Institute.

Nazarko, J. (Eds.). 2012. Badanie ewaluacyjne projektów foresight realizowanych $w$ Polsce. Warszawa: MNiSW.

Nazarko, J.; Ejdys, J.; Halicka, K.; Olszewska, A.; Kononiuk, A.; Gudanowska, A.; Magruk, A. 2012. Analiza doświadczeń $w$ zakresie metod technology mapping oraz technology roadmapping. Część I Polskie doświadczenia, report - project Narodowy Program Foresight - wdrożenie wyników.

Phaal, R.; Farrukh, C. J. P.; Probert, D. R. 2000. Technology Roadmapping: linking technology resources to business objectives, Managing Innovative Manufacturing (MIM 2000). Birmingham: Aston Business School.

Phaal, R.; Farrukh, C. J. P.; Probert, D. R. 2005. Developing a technology roadmapping system, technology management: a unifying discipline for melting the boundaries, IEEE Conference Publications: 99-111.

Phaal, R.; Farrukh, C.; Probert, D. 2001. T-Plan: Fast start to technology roadmapping - planning your route to success. Cambridge: Institute for Manufacturing.
Phaal, R.; O’Sullivan, E.; Routley, M.; Ford, S.; Probert, D. 2011. A framework for mapping industrial emergence, Technological Forecasting and Social Change 78(2): 217-230. http://dx.doi.org/10.1016/j.techfore.2010.06.018

Probert, D.; Radnor, M. 2003. Frontier experiences from industry - academia consortia, Research Technology Management 46(2): 27-30. http://dx.doi.org/10.1109/emr.2003.24902

Rogut, A.; Piasecki, B.; Klepka, M.; Czyż, P. 2009. Dobre praktyki wdrażania regionalnych strategii innowacji w Polsce. Warszawa: PARP.

Saritas, O.; Aylen, J. 2010. Using scenarios for roadmapping: the case of clean production, Technological Forecasting and Social Change 77(7): 1061-1075. http://dx.doi.org/10.1016/j.techfore.2010.03.003

Skulimowski, A. M. J. 2009. Metody roadmappingu i foresightu technologicznego, Chemik - Nauka Technika Rynek 5: 1-8.

Tindigarukayo, J. K. 2012. Benchmarking the citizen's charter in Jamaica: an Empirical Evaluation [online], [cited 01 December 2015]. Available from Internet: http://sta.uwi.edu/conferences/ salises/documents/Tindigarukayo\%20J.pdf

Yan, Xu; Chung-Hsing, Yeh. 2011. An integrated approach to evaluation and planning of best practices, Omega 40(1): 65-78.

Watson, R. 2012. Trends and technology timeline $2010+$ a roadmap for the exploration of current and future trends, in Future Files. A brief history of the next 50 years. London-Boston: Nicholas Brealey Publishing.

Wierzbicki, A. P.; Nakamori, Y. 2007. Creative environments: issues of creativity for the knowledge civilization age. Berlin-Heidelberg: Springer Verlag. http://dx.doi.org/10.1007/978-3-540-71562-7

Willyard, C. H.; McClees, C. W. 1987. Motorola's technology roadmap process, Research Management 30(5): 13-19. 